\title{
The Role of Waqf Land in Increasing the Benefit of the Community in the Era of Globalization
}

\author{
Mulyono Jamal ${ }^{1}$, Jarman Arroisi ${ }^{2}$, Khurun'in Zahro'3, Nia Puji Agustin ${ }^{4}$ \\ mulyonojamal@unida.gontor.ac.id ${ }^{1}$,jargon221169@gmail.com², \\ khuruninzahro@unida.gontor.ac.id ${ }^{3}$,niagp3@gmail.com ${ }^{4}$ \\ Fakultas Syariah dan Pascasarjana Prodi Hukum Ekonomi Syariah UNIDA Gontor ${ }^{1}$, \\ Fakultas Ushuluddin dan Pascasarjana Prodi Akidah Filsafat UNIDA Gontor ${ }^{2}$, \\ Pascasarjana Prodi Hukum Ekonomi Syariah UNIDA Gontor ${ }^{3}$, \\ Pascasarjana Prodi Hukum Ekonomi Syariah UNIDA Gontor ${ }^{4}$
}

\begin{abstract}
Land waqf as one of the economic instruments with social dimension, has a great contribution to the benefit of the people both in the fields of economics, education and health. However, the Indonesian Muslim community is still not optimal in managing this waqf land asset.This study aims determine how the role of waqf land in increasing the benefit of the people by the leader of Bojonegoro's Nadlatul Ulama Branch (PCNU). This research is a field research with qualitative methods and uses a traingulation approach. The results of this study indicate that waqf land on Bojonegoro PCNU managed by Bojonegoro's PCNU cadre is in accordance with Wakif's wishes and even waqf assets grow and develop, making endowments a new pillar in community economic development and contributing to economic independence both materially and nonmaterially. This can be achieved because the management of waqf land is considered important by the director of the Bojonegoro PCNU for the benefit of the people towards baldatun toyyibah.
\end{abstract}

Keywords: Waqf Management, Land of Waqf, Nazhir, PCNU of Bojonegoro

\section{Pendahuluan}

Wakaf sebagai salah satu potensi pranata keagamaan yang bersifat ekonomis, harus dikelola dan dikembangkan agar menjadi suatu instrumen yang mampu memberikan jawaban riil ditengah problematika kehidupan masyarakat. Sayangnya, masyarakat Indonesia masih banyak yang kurang memahami permasalahan wakaf dalam Islam secara benar dan menyeluruh. Hal ini terbukti dengan banyaknya wakaf yang dikelola masyarakat Indonesia masih seperti pada zaman sebelum Islam,misalnya wakaf untuk tempat ibadah, kuburan, dan wakaf lain yang tidak produktif. Berawal dari problematika tersebut, wacanawakaf produktif dan wakaf uangpun kembali digaungkan di Indonesia oleh beberapa tokoh, pemikir dan cendekiawan Indonesia.[1]

Walaupun wakaf merupakan salah satu filantropi Islam yang hukumnya sunnah, tetapifilantropi ini dapat berkembang dengan baik di beberapa negara muslim, seperti di Saudi Arabia, Mesir, Turki, Yordania, pemerintah Qatar, Kuwait, dan lain-lain. Itu semuatidak terlepas daricampur tangan kaum Muslimin yang merasakan dan meyakini bahwa wakaf sangat berperanpentingbagi kemaslahatan umat.

Perkembangan wakaf di Indonesia kian hari kian meningkat. Halitu terlihat dari bertambahnya jumlah dan objek aset wakaf, baikberupa wakaf bergerak seperti uang maupunwakaf tidak bergerak sepertitanah dan lainnya, yang tersebar di berbagai penjuruIndonesia. Namun demikian, perkembangan praktik danpenambahan jumlah objek aset wakaf juga harus diimbangi dengan peningkatan studi tentang wakaf di Indonesia agar aset wakaf yang luar biasa besar dan sangat potensial ini dapat dikembangkan dan dikelola secara baik, sehingga wakaf dapat menjadi pilar barudalam pembangunan ekonomi masyarakat.Misalnya, selain wakaf uang, adapula wakaf tanah yang menjadi salah satu instrumen ekonomis yang berdimensi sosial dan jelas memiliki kontribusi yang besar bagi kemaslahatan umat apabila dikelola dandidayagunakan sedemikian rupa, baik di bidang ekonomi, pendidikan, kesehatan dan lain sebagainya. 
Konsep wakaf yang sangat strategis untuk pemberdayaan masyarakat, pembangunan ekonomi bangsa dan kesejahteraan sosial harus benar-benar dibangun dengan dinamika konteks kebutuhan masyarakat pada zamannya. Konsep wakaf yang dibutuhkan tidak hanya bersifat terbatas dan terformat ke arah kegiatan yang bersifat keagamaan saja. Namun, pengelolaan dan pemberdayaan wakaf di era kontemporer lebih dituntut untuk menerapkan pola paradigma produktif dalam arti keabadian manfaat, profesionalitas, tanggung jawab dan keadilan sosial sehingga memiliki keterampilan dalam mengelola wakaf secara produktif.

Tanah wakaf, sudah jelas terlihat bahwa aset tanah wakaf di Indonesia yang begitu banyak tersebar sampai 49.016,57 hektar dapat mendukung aset-aset sosial lainnya, terlebih lagi masyarakat yang sadar betapa berharganya nilai tanah setiap jengkalnya bagi kebutuhan masyarakat. Hal ini apabila digali terus manfaatnya dengan cara giat mengembangkannya sudah pasti potensi yang akan dihasilkan sangat berguna untuk meningkatkan untuk kepentingan keagamaan, sosial maupun ekonomi.Seharusnya Indonesia dapat mengambil contoh dari negara sekuler seperti Singapura dan Thailand yang memiliki praktik wakaf produktif yang telah benarbenar digeluti oleh minoritas Muslim disana sehingga seluruh lapisan masyarakat dapat turut merasakan dampaknya.[2] Pengelolaan dan pemberdayaan wakaf tanah di negara-negara tersebut dilakukan secara maksimal, sehingga hasil dari pengelolaan wakaf tanah tersebut dapat dipergunakan untuk menunjang kemaslahatan umat.

Jika pemerintah merupakan pihak yang akan bertanggung jawab dalam pengelolaan aset wakaf di Indonesia, pihak yang berwajib ini harus dapat dipercaya untuk mengubah aset wakaf menjadi lebih potensial. Dengan demikian, makalah ini sangat menarik untuk membahas tentang peran tanah wakaf dalam meningkatkan kemaslahatanumat khususnya di negara kita Indonesia.Maka, penting kiranya makalah ini untuk mengkaji lebih dalam mengenai pengelolaan tanah wakaf agar kita dapat mengetahui peran atau pentingnya tanah wakaf bagi kemaslahatan umat oleh nadzir yang profesional guna meraihbaldatun thoyyibatun di dunia dan kebaikan (falah) di akhirat. 


\section{Pengertian Wakaf}

Wakaf (waqf) di dalam bahasa Arab berarti habs (menahan). Dikatakan waqafa-yaqifuwaqfan artinya habasa-yahbisu-hasban. Menurut istilah syara' wakaf berarti menahan harta dan memberikan manfaatnya di jalan Allah.[3] Menurut arti bahasanya, waqafa berarti menahan atau mencegah, misalnya وقفت عن اسير" saya menahan diri dari berjalan".[4] Disebut menahan karena wakaf ditahan dari kerusakan, penjualan dan semua tindakan yang tidak sesuai dengan tujuan wakaf. Dikatakan menahan, juga karena manfaat dan hasilnya ditahan dan dilarang bagi siapapun selain dari orang-orang yang termasuk berhak atas wakaf tersebut.[5]

Definisi wakaf menurut ulama klasik diwakili olehulama-ulama mazhab. Hanafiyah mengartikanwakaf sebagai menahan materi benda (al-'ain) milik wakifdan menyedekahkan atau mewakafkan manfaatnya kepadasiapapun yang diinginkan untuk tujuan kebajikan.[6] Malikiyah berpendapat, wakaf adalah menjadikanmanfaat suatu harta yang dimiliki (walaupun pemilikannyadengan cara sewa) untuk diberikan kepada orang yang berhakdengan satu akad (shighat) dalam jangka waktu tertentusesuai dengan keinginan wakif.[7] Syafi'iyah mengartikan wakaf dengan menahan hartayang dapat memberikan manfaat serta kekal materi bendanya (al'ain) dengan cara memutuskan hak pengelolaan yang dimilikioleh wakif untuk diserahkan kepada nadzir yang dibolehkanoleh syariah.[8] Hanabilah mendefinisikan wakaf denganbahasa yang sederhana, yaitu menahan asal harta (tanah) danmenyedekahkan manfaat yang dihasilkan.[9]

Dalam hukum fikih, wakaf berarti menyerahkan suatu hak milik yang tahan lama zatnya kepada seseorang atau nadzir (penjaga wakaf), atau kepada suatu badan hukum pengelola dengan ketentuan bahwa hasil atau manfaatnya digunakan kepada hal-hal yang sesuai dengan ajaran syariat Islam. [10]

Menurut Kompilasi Hukum Islam (KHI) pada buku III, tentang Hukum Perwakafan Bab 1 Pasal 215 ayat (1), pengertian wakaf adalah perbuatan orang atau badan yang memisahkan sebagian dari benda miliknya dan melembagakannya, untuk selama-lamanya untuk kepentingan ibadah atau keperluan umum lainnya sesuai dengan ajaran Islam. [11]

Fatwa MUI menyatakan bahwa wakaf adalah "Penahanharta yang dapat dimanfaatkan tanpa hilang benda ataupokoknya dengan cara tidak melakukan tindakan hukumterhadap benda tersebut (menjual, menghibahkan, atau mewariskannya), untuk digunakan (hasilnya) pada sesuatu yang diperbolehkan (tidak haram). Undang-Undang No. 41 Tahun 2004 tentang Wakaf menyebutkan definisi wakaf sebagai: "Wakaf adalah perbuatan hukum wakif untuk memisahkan atau menyerahkan sebagian harta benda miliknya untuk dimanfaatkan selamanya atau jangka waktu tertentu sesuai dengan ketentuannya guna keperluan ibadah atau kesejahteraan umum menurut syariah". Definisi ini mengakomodasi semua definisi yang disampaikan oleh ulama, yaitu dengan membolehkan wakaf permanen dan temporer, wakaf keluarga dan umum, wakaf bergerak maupun wakaf tidak bergerak termasuk wakaf uang. [12]

Dari berbagai rumusan pengertian tentang wakaf, dapat diartikan bahwa wakaf adalah menyerahkan suatu hak milik yang tahan lama zatnya kepada seseorang atau nadzir (pemelihara atau pengurus wakaf) atau kepada suatu badan pengelola dengan ketentuan bahwa hasil atau manfaatnya dipergunakan sesuai dengan ajaran Islam. Benda yang diwakafkan tidak lagi menjadi hak milik yang mewakafkan dan bukan pula milik tempat menyerahkan, tetapi menjadi milik Allah.[13] Jadi, wakaf artinya menahan yaitu menahan suatu benda yang kekal zatnya untuk diambil manfaatnya bagi kemaslahatan umum.[14]

\section{Metodologi Penelitian}

Jenis penelitian ini adalah penelitian lapangan (field research) yang dapat disebut sebagai penelitian empiris,[15] dengan kaedah penelitian secara kualitatif. [16] Tiga teknik pengumpulan data utama yang biasa digunakan dalam kajian secara kualitatif menurut Merriam ialah bukti dokumen, interview dan observasi.[17] Ketiga teknik ini disebut dengan istilah 'triangulation'.Dalam penelitian ini, Nadzir PCNU Kabupaten Bojonegoro sebagai bahan data 
primer diklasifikasikan dengan mengikuti kaidah cluster-quota sampling yang dipilih secara Snowball Sampling sehingga memberikan gambaranterhadap urgensipengelolaan tanah wakaf bagi kemaslahatan umat olehNadzir PCNU Kabupaten Bojonegoro.

\section{Tanah Wakaf di Indonesia}

Kekayaan aset wakaf berupa tanah di Indonesia yang tersebar di 33 provinsi terbilang besar. Berdasarkan data dari Direktorat Pemberdayaan Wakaf Kementerian Agama RI tahun 2018, jumlah data tanah wakaf di Indonesia sebanyak 353.296 lokasi dengan luas total mencapai 49.016,57 hektar, sedangkan yang sudah bersertifikat wakaf sebanyak $62,89 \%$ dan yang belum bersertifikat wakaf sebanyak $37,11 \%$. [18]

Dari data diatas dapat diketahui bahwa tanah wakaf sebenarnya memiliki potensi yang sangat besar, tetapi tanah wakaf tersebut belum dikelola secara produktif, sehingga aset wakaf di Indonesia belum dapat berperan maksimal dalam memberdayakan ekonomi umat.[19] Hal ini terbukti dengan adanya data dari Direktorat Jenderal Bimbingan Masyarakat Islam Kementerian

Agama Republik Indonesia yang menyatakan bahwa penggunaan tanah wakaf berupa masjid sebesar $45 \%$, mushalla sebesar $28 \%$, sekolah sebesar $11 \%$, makam sebesar $5 \%$, pesantren sebesar $3 \%$ dan sosial lainnya berupa $8 \%$ [20] Hal ini seperti tercantumdalam tabel berikut:

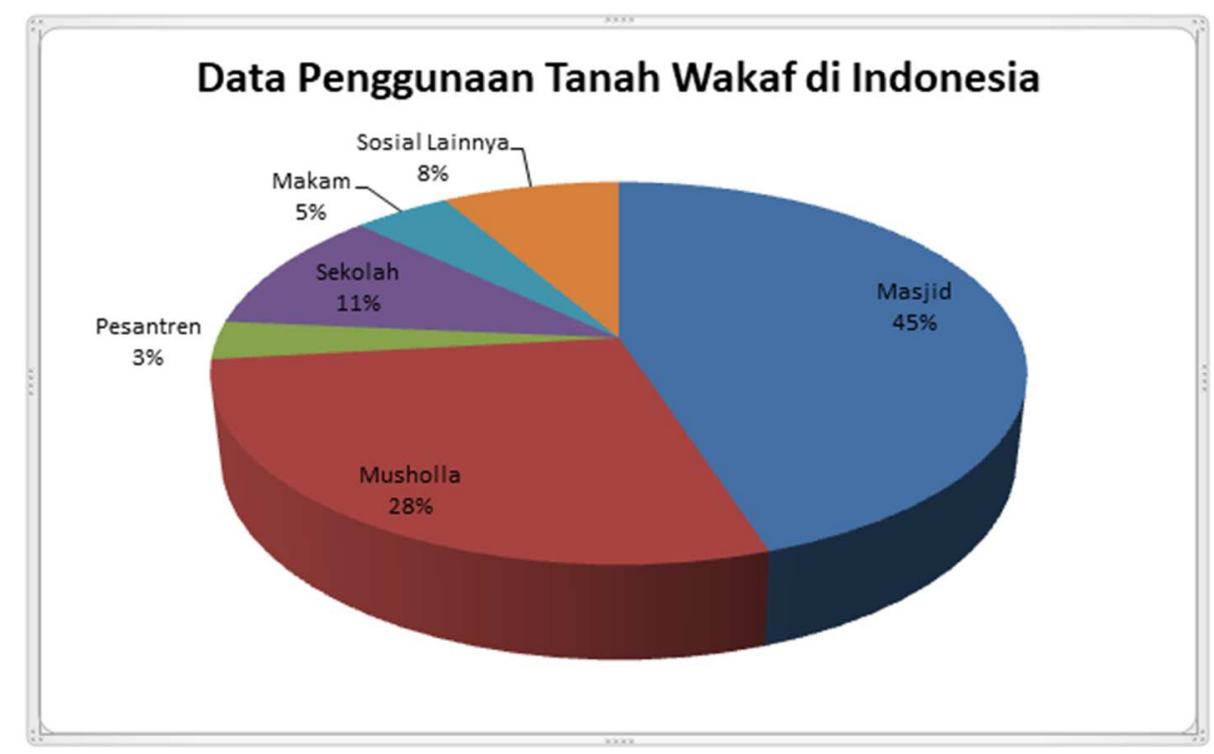

Gambar 1.1 : Data Pengguna Tanah Wakaf di Indonesia

Salah satu lembaga profesional nadzir yang menangani tanah wakaf di Kabupaten Bojonegoro adalah PCNU yang bertugas untuk mengurus, mengelola serta mengembangkan tanah dan bangunan serta harta benda wakaf lainnya milik Nahdlatul Ulama [21] PCNU ini selain memiliki aset tanah wakaf yang lebih banyak, juga telah mendirikan berbagai macam bangunan diatasnya, sehingga dapat dikelola bagi kemaslahatan umat, karena tanah wakaf yang dikelola oleh lembaga tersebut tidak hanya mendukung pengembangan ilmu pengetahuan saja, tetapi juga menyediakan berbagai sarana dan prasarana yang dibutuhkan oleh masyarakat,seperti di bidang pendidikan adanya sekolah-sekolah dan pondok-pondok di Bojonegoro, di bidang kesehatan ada RSI. Abdul Wahid, di bidang ekonomi ada BMT NU Ngasem Bojonegoro, Rusunawa PCNU, di bidang sosial adanya Kantor PCNU, tempat pemakaman, dan lain-sebagainya.

Pemberdayaan tanah wakaf tersebut dapat dilakukan sedemikian rupa, sehingga tanah wakaf dapat dijadikan sebagai berikut: Pertama, aset yang menghasilkan produk barang atau jasa. Hal ini memerlukan perencanaan yang matang, termasuk bentuk dan kemungkinan pengembangan serta tantangan dan hambatannya. Kedua, aset yang berbentuk investasi usaha. Artinya, ketika nadzir telah dapat mengumpulkan keuntungan dari pengelolaan tanah wakaf, keuntungan tersebut 
dapat diinvestasikan kepada lembaga keuangan syariah yang kredibel maupun kepada pengusaha dan pihak-pihak lain yang amanah dan profesional.

Aset wakaf yang besar ini jika tidak dikelola dan diberdayakan dengan baik pasti akan banyak menimbulkan permasalahan-permasalahan seperti hilangnya sejumlah aset wakaf yang pada akhirnya wakaf tidak sesuai dengan fungsi dan tujuannya dan tidak dapat digunakan untuk kepentingan umat. [22] 


\section{Peran Nadzir Wakaf di Indonesia}

Salah satu kunci pengelolaan wakaf terletak pada eksistensi pengelola wakaf, terutama nadzir dan tim kerja yang solid untuk memaksimalkan peran wakaf.[23] Apalagi tanah wakaf yang termasuk benda tidak bergerak memerlukan adanya nadzir profesional guna mengelola aset wakaf ini.

BerdasarkanUndang-Undang Republik Indonesia No.41 Tahun 2004 tentang Wakaf, pada Bab II Pasal 9-14 tentang nazhir,[24] dan Peraturan Pemerintah No. 42 Tahun2006 tentang Pelaksanaan UU No.41 Tahun 2004 tentang wakaf pasal 2-14 telahmembuktikan bahwa nazhir mempunyai peran besar guna mengelola dan mendayagunakan aset wakaf, baik itu wakaf uang, tanah atau wakaf produktif lainnya.

Abdurrahman Kasdi, dalam penelitiannya Peran Nadzir dalam Pengembangan Wakaf yang menyimpulkan bahwaeksistensi wakaf dan pemberdayaannya sangat tergantungpada nazhir. Nadzir berkewajiban mengerjakan segala sesuatuyang layak untuk menjaga dan mengelola harta wakaf. Nazhirterdiri dari nadzir perorangan, organisasi atau badan hukum.Pengelolaan wakaf lebih potensial diterapkan oleh nadzirlembaga, baik organisasi maupun badan hukum, dibandingkandengan nadzir perseorangan yang berbasis manajementradisional.Secara umum, pengelolaan wakafdapat terarah dan terbina secara optimal, apabila nadzirnyaamanah (dapat dipercaya) dan profesional. [25]

Setelah diresmikannya UU No.41 Tahun 2004, kemudian diteruskan dengan dibentuknya Badan Wakaf Indonesia (BWI) sebagai lembaga independen yang secara khusus mengelola dana wakaf dan beroperasi secara nasional. Tugas dari lembaga ini adalah untuk memajukan dan mengembangkan perwakafan nasional di Indonesia. BWI berkedudukan di ibukota negara dan dapat membentuk perwakilan di provinsi atau kabupaten atau kota sesuai dengan kebutuhan.[26]

Tugas dan wewenang BWI begitu banyak lagi besar seperti membina nadzir, memberikan persetujuan dan/atau izin atas perubahan peruntukan dan status harta benda wakaf, melakukan pengelolaan dan pengembangan harta benda wakaf berskala nasional dan internasional, memberikan saran dan pertimbangan kepada pemerintah dalam penyusunan kebijakan di bidang perwakafan, dan lain-lain.[27] Namun, harus kita sadari bersama bahwa tidak banyak perkembangan wakaf di Indonesia yang signifikan. Tidak dapat dimungkiri lagi, kesemuanya itu membutuhkan sumber daya manusia (SDM) yang kompeten dan profesional. Pun demikian, kita telah mengetahui bersama bahwa BWI juga bekerjasama dengan berbagai pihak guna menjalankan amanah nan suci ini.

Namun, inisiatif-inisiatif itu masih belum maksimal jika dibandingkan dengan jumlah aset wakaf dalam bentuk tanah di Indonesia. Misalnya saja, data yang diperoleh oleh lembaga di bawah naungan Kementrian Agama atau BWI tidak sesuai dengan fakta yang ada. Hal itu disebabkan para nadzir kurang memahami akan pentingnya data yang accountable karena akuntabilitas juga merupakan solusi pengelolaan wakaf. Oleh karena itu, penting kiranya diadakan survei di lapangan mengenai hal tersebut, agar menghasilkan data yang jelas dan potensi serta kondisi finansial aset wakaf. 


\section{Peran Tanah Wakaf dalam Meningkatkan Kemaslahatan Umat}

Di masa pertumbuhan ekonomi yang cukup memprihatinkan seperti sekarang ini, sesungguhnya peranan tanah wakaf di samping instrumen-instrumen lainnya, dapat dirasakan manfaatnya untuk meningkatkan kemaslahatan masyarakat, baik itu di bidang ekonomi, pendidikan maupun kesehatan, apabila tanah wakaf diberdayakan dengan baik dan proporsional (tepat guna dan produktif). Peruntukan tanah wakaf di Indonesia yang kurang mengarah pada pemberdayaannya dan cenderung hanya untuk kegiatan-kegiatan ibadah khusus (ibadah makhdah) lebih karena dipengaruhi oleh keterbatasan umat Islam pada pemahaman wakaf, baik mengenai harta yang diwakafkan maupun nadzir (pengelola, pengawas harta wakaf).

Oleh karenanya, pengembangan dan peningkatan kapasitas para nadzirpun harus dilakukan. Para pengelola wakaf sudah seharusnya secaraperlahan merubah orientasi pengurusan wakaf menjadi profesional,walau tidak melulu harus produktif. Aset wakaf sebisa mungkin tidaksaja memiliki nilai sosial, tetapi juga nilai ekonomis. Tanah wakaf yangterabaikan atau belum termanfaatkan, misalnya, bisa dimanfaatkanmenjadi gedung perkantoran, ruko, swalayan, pabrik, kontrakan,restoran, bank cabang pembantu, atau TK ataupun PAUD. Lebih jauh,wakaf dengan peruntukan pendirian masjid pun bisa dimodifikasidengan membangun gedung serbaguna baik di lahan yang sama ataudi bagian bawah masjid, yang dapat disewakan untuk acara resepsipernikahan, ruang pertemuan, ruang rapat, dan mungkin untukacara seminar. Sehingga, operasional masjid dapat terbantu denganpemasukan dari ruang/gedung pertemuan tersebut.

Adapun secara bahasa, maslahah berarti kebaikan.[28] Di dalam kamus Munjid mengartikan maslahah sebagai sesuatu yang mendatangkan kebaikan yaitu perbuatan-perbuatan manusia yang dapat mendatangkan manfaat kepada diri sendiri serta kaumnya.[29] Dikatakan juga maslahah adalah lawan dari kerusakan atau kebaikan atau al-khair.[30] Pengertian maslahah menurut istilah dapat dipahami dari pendapat para ulama silam ketika membahas tentang maslaha dan munasab. Namun, para ulama terdahulu masih belum sepakat dengan definisi maslahah dan batasannya serta berbeda-beda terhadap penerimaannya.[31] Menurut Ibn Asyur maslahah sebagai perbuatan yang menghasilkan kebaikan dan manfaat yang bersifat terus menerus baik untuk orang banyak maupun individu.[32] Karena itu, dari sekian banyak definisi maslahah dapat disimpulkan bahwa maslahah adalah segala sesuatuyang dilakukan untuk mencapai kebaikan hidup di dunia dan di akhirat dengan berdasarkan pada perspektif Islam yaitu dengan memelihara agama, jiwa, akal, keturunan dan harta.

Tujuan wakaf dalam pandangan fikih klasik dan kontemporer tidaklah jauh berbeda karena sumberajaran pun sama, yaitu untuk meraih kemaslahatan baik di dunia maupun di akhirat, hanya variasi transaksiekonomi modern yang lebih tinggi berimplikasi padamodel pemberdayaan wakaf yang lebih beragam pula.Karena itu, pengelolaan wakaf hendaknya dipergunakan untuk keperluan sosial, baik di bidang pendidikan, ekonomi dan kesehatan seperti meningkatkan pendidikan Islam, pengembangan rumah sakit Islam, bantuan pemberdayaan eknomi umat, bantuan penelitian, bantuan atau pengembangan sarana dan prasarana ibadah dan lain sebagainya sebagai korelasi logis banyaknya pahala dengan banyaknya kemanfaatan.

Wakaf tanah, apabila tanah wakaf dikelola dan diberdayakan dengan baik oleh nadzir, misalnya dengan didirikannya rumah sakit, maka dapat memberikan kontribusi bagi orang yang kurang mampu dengan peringanan biaya berobat. Berdasarkan uraian yang tersebut di atas, dapat dipahami bahwa wakaf termasuk di dalamnya wakaf tanah mempunyai kontribusi solutif terhadap persoalan-persoalan ekonomi kemasyarakatan dalam arti kata wakaf tanah mengandung potensi sumber daya ekonomi umat.

Salah satu konsepsumber daya ekonomi apabila dikaitkan dengan tanah mungkin dapat dipahami, bahwatanah merupakan "Natural Resources" (sumber daya alam), sedangkan manusia sebagai"Human Resources" (sumber daya manusia). Dalam pengalaman sejarah, ekonomisuatu bangsa dan negara akan dapat tumbuh dan berkembang apabila kedua faktortersebut dapat dikelola sebaik mungkin dengan menggunakan penemuan-penemuanbaru dalam iptek (ilmu pengetahuan dan teknologi). Bertolak dari pemikiran di atas,maka tanah wakaf sebagai suatu lembaga sosial 
Islam, pada hakekatnya mempunyaifungsi yang sama dapat digunakan sebagai salah satu sumber daya ekonomi. Artinyapenggunaan tanah wakaf tidak terbatas hanya untuk keperluan kegiatankegiatantertentu saja berdasarkan orientasi konvensional, seperti pendidikan, masjid, pondokpesantren, panti-panti asuhan, dan lain-lain, tetapi tanah wakaf dalam pengertian makrodapat pula dimanfaatkan untukkegiatan-kegiatan ekonomi lainnya, seperti rumah sakit,pertokoan, pertanian, peternakan, industri, pertambangan, real estat, hotel, restauran,dan lainlain. Kedudukan tanahnya tetap sebagai tanah wakaf, tetapi hasilnya dapatdimanfaatkan secara lebih optimal. Hal ini merupakan salah satu alternatif untukmengoptimalkan fungsi wakaf itu sendiri[33].

Rendahnya produktivitas tanah wakaf di Indonesia menyebabkan menurunnya pemanfaatan harta wakaf. Hal ini disebabkan antara lain:

1. Masih cukup banyak para nadziryang mengelola wakaf dengan cara konvensional, bila tidak ingindisebut tradisional. Apa yang dibayangkan para nadzir sebagai wakafmasih sangat sederhana. Wakaf masih dipahami sebagai aktivitasmenyerahkan sebagian harta benda guna dimanfaatkan selamanya atauuntuk jangka waktu tertentu untuk dimanfaatkan sebagai keperluanibadah yang notabenenya tidak boleh dibisniskan.

2. Masih banyak para wakif yang mewakafkan hartanyamemang diperuntukkan untuk pembangunan tempat ibadah. Apalagi,gejala ini menjadi semakin krusial karena kebanyakan para wakif,dengan meminta pertolongan pada anggota keluarganya yang masihhidup, mewakafkan hartanya sesudah mereka meninggal. Artinya,status harta wakaf tersebut menjadi wasiat bagi keluarganya yang mautidak mau, harus dijalankan.

3. Masih banyak anggapan di masyarakat bahwa menyalurkan harta wakaf guna dijadikan pemberdayaan ekonomi berpotensi besar dalam menyulut konflik. Bagi masyarakat yang berada pada situasiini, wakaf merupakan salah satu bentuk ibadah terhadap Ilahi yangsifatnya sangat sakral. Bila niat yang awalnya ditujukan untuk ibadahini kemudian berujung pada konflik dan mengganggu kekhusukanibadah, sebaiknya dari awal harta wakaf langsung sajadiperuntukkan menjadi masjid atau mushala. Padahal contohcontohawal wakaf pada masa Nabi yang tersebar adalah wakaf perkebunan.Namun, wakaf perkebunan atau lainnya yang produktif ini belummenjadi tren karena memang perkembangan ekonomi terpisahdengan perkembangan keagamaan.

Kondisi seperti ini disamping pemerintah harus mengembangkan ekonomi yang berbasis kerakyatan, umat Islam sendiri harus aktif mencari alternatif-alternatif agar dapat meningkatkan kemaslahatan umat. Karena itu, salah satu alternatif yang dapat dilakukan oleh umat Islam adalah dengan mengelola tanah wakaf secara produktif.

\section{Kesimpulan}

Harta wakaf harus dipergunakan dalambidang kemaslahatan, artinya tidak boleh digunakandalam urusan haram. Oleh karena itu, sebagian fuqahamenjelaskan bahwa bidang kemaslahatan adalah segalaurusan yang diperbolehkan.[34]Jika pemerintah dan masyarakat berkesinambungan dalam mengelola tanah wakaf, diharapkan dapat menjadi masukan kepada para regulator dalam mengelola tanah wakaf guna menghadapi tantangan sekaligus peluang ini. Selain itu, jugasebagai role model pengelolaan aset wakaf bagi nadzir sekaligus Badan Wakaf Indonesia(BWI) dalam pembinaan dan pengawasan nazhir wakaf, baik itu personal ataupun organisasi dalam mengeloladan memberdayakan aset wakaf. Disinilah peran tanah wakaf digaungkan untuk meningkatkan kemaslahatan umat pada umumnya dan masyarakat Indonesia pada khususnya.

Selain itu, dibutuhkan juga nadzir yang profesional di bidangnya, baik itu nadzir perorangan maupun nadzir organisasi bahkan nadzir badan hukum, karena belum tentu wakaf yang besar lagi banyak dapat dikelola dengan baik tanpa adanya campur tangan nadzir yang profesional. 
Alangkah baiknya apabila di negara kita Indonesia ini ada akademisi dan praktisi yang benar-benar mengetahui, memahami dan mendalami akan pentingnya manajemen pengelolaan dan pemberdayaan wakaf, baik itu untuk wakaf konsumtif dan terutama wakaf produktif karena, untuk mengelola aset wakaf tersebut, diperlukan kualitas SDM para nadzir yang profesional. Apalagi aset tanah wakaf di Indonesia yang sangat luas lagi potensial.Walaupun pemerintah sudah mempunyai pedoman pengelolaan wakaf produktif, tetapi pada kenyataannya masih banyak asetaset wakaf yang terbengkalai dan perlu dikaji serta diteliti lebih intensif guna membangun ekonomi umat yang berbasis maslahah atau kemaslahatan.

\section{Refrences}

[1] Sirodjul Munir, Bendahara Badan Wakaf Indonesia, Kemitraan Usaha dalam Wakaf Produktif, http://bwi.or.id/index.php/ar/home/151-kemitraan-usaha-dalam-wakaf-produktif, diakses tanggal 10 Mei 2018.

[2] Alaidin Koto dan Wali Saputra, "Wakaf Produktif di Negara Sekuler: Kasus Singapura dan Thailand", Jurnal Sosial Budaya, 02 Desember 2016.

[3] Sayyid Sabiq, Fikih Sunnah, Jilid 14, Mu'ammalah, Terj. Mudzakir AS, Cet. 4, (Bandung: Alma'arif, 1994), hal. 148

[4] Muhammad Jawad Mughniyah, Fiqih Lima Mazhab, Terj. Masykur A.B, Afif Muhammad \& Idrus AlKaff, (Jakarta : Penerbit Lentera, 2007), hal. 635.

[5] Monzer Kahf, Manajemen Wakaf Produktif, (terjemahan),(Jakarta: Khalifa, 2007), hal.45.

[6] Al-Imam Kamal al-Din Ibn 'Abd al-Rahid al-Sirasi Ibn al-Humam, Sharh Fath al-Qadir, Jilid. 6. (Beirut: Dar al-Kutub al-Ilmiyyah,1970), hal. 203.

[7] Syams al-Din al-Syaikh Muhammad al-Dasuqi, Hasyiyah al-Dasuqi 'ala al-Syarh al-Kabir, Juz 2, (Beirut: Dar al-Fikr, tt.), hal. 187.

[8] Muhammad al-Khatib al-Syarbini, Mughni al-Muhtaj, Juz 2, (Kairo: Syarikah Maktabah wa Matba'ah Mustafa al-Babi al-Halabi waAwladih, 1958), hal. 376.

[9] al-Kabisi, Hasyiyatu al-Qalyubi ala Syarh al-muhalla li al-Minhaj(ttp,ttp).

[10]Harun Nasution, Ensiklopedia Islam Indonesia, Djambatan: IAIN Syarif Hidayatullah,t.th, hal. 981.

[11]Lutfi El Falahy, "Alih Fungsi Tanah WakafDitinjau Dari Hukum Islam danUndang-Undang Nomor 41 Tahun 2004 Tentang Wakaf”, Al-Istinbath: Jurnal Hukum Islam, Vol. 1, No. 2, 2016, hal. 127.

[12]Ahmad Furqon, Wakaf Sebagai Solusi Permasalahan Dunia Pendidikan Di Indonesia, Jurnal At-Taqaddum, Vol. 4, No. 2, Nopember 2012, hal. 47.

[13]Abdul Halim, Hukum Perwakafan di Indonesia, (Ciputat: Ciputat Pres, 2005), hal. 7.

[14]A. Manan Idris, et.al., Aktualisasi Pendidkan Islam Respon Terhadap Problematika Kontemporer, (Jakarta: Hilal Pustaka, 2009), hal. 252.

[15]LexyJ Moleong,Metodologi Penelitian Kualitatif, (Bandung: PT Remaja Rosdakarya,2006), hal. 4.

[16]Boedi Abdullah dan Beni Saebani, Metode Penelitian Ekonomi Islam, (Bandung: Pustaka Setia, 2014). hal. 49.

[17]Merriam, S.B., Case study research in education: A qualitative approach. 3rd Ed, (San Francisco: JosseyBass Publishers, 1990), hal. 73.

[18]Data Tanah Wakaf, http://siwak.kemenag.go.id/index.php, diakses tanggal 11 September 2018, pukul 21.20.

[19]Uswatun Hasanah, Urgensi Pengawasan Dalam Pengelolaan Wakaf Produktif, Jurnal Al-Ahkam, Vol. 22, No. 1, April 2012. hal. 67.

[20]Data Tanah Wakaf, http://siwak.kemenag.go.id/index.php, diakses tanggal 10 Mei 2018.

[21]Susunan Lengkap Pengurus LWPNU 2015-2020, http://www.nu.or.id/post/read/62279/susunan-lengkappengurus-lwpnu-2015-2020, diakses tanggal 10 Mei 2018.

[22]Amiq Fahmi, Edi Sugiarto, Peningkatan Keterampilan Nadzir, PPAIW KUA, dan Pengelenggara Syariah Melalui Pelatihan manajemen Aset Wakaf Berbasis Teknologi Informasi, Fakultas Teknik Universitas Muria Kudus, 2016, ISBN: 978-602-1180-33-4. hal. 277.

[23]Sherafat Ali Hasymi, Management of Waqf: Past and Present, dalam Hasmat Basyar (ed.), Management andDevelopment of Auqaf Properties, (Jeddah: Islamic Research and Training Institute and Islamic Development Ban, 1987), hal. 21.

[24]Badan Wakaf Indoensia, Himpunan Peraturan Perundang-undangan Tentang Wakaf, hal. 7-9.

[25]Abdurrahman Kasdi, Peran Nadzir dalam Pengembangan Wakaf, Jurnal Zakat dan Wakaf, Vol. 1, No. 2, Desember 2014, hal. 225.

[26]Rachmadi Usman, Hukum Perwakafan di Indonesia,(Jakarta: Sinar Grafika, 2009), hal. 132.

[27]Tugas dan Wewenang BWI, https://bwi.or.id/index.php/ar/tentang-bwi/tugas-dan-wewenang.html, diakses tanggal 1 Juni 2018.

[28]Ibn Mandzur, Lisan al-Arab, Juz. 2, Cet. 3, (Beirut: Dar Sadir, 1994), hal. 516. 
[29]Luwis Ma'luf al-Yasu'i, al Munjid fi al-Lughoh wa al-Adab wa al-Ulum, Cet. 19, (Beirut: Maktabah alKatulikiyah), hal. 432.

[30]Mahmud abd ar-Rahman abd Abd al-Qadir al-Razi, Mukhtar al-Ahfadz al-Fiqhiyyah Maslahah, Juz 3, (Kairo: Dar al-Fadhilah, 1999), hal. 300.

[31]Mustafa Zayd, al-Maslahah fi al-Tasyri' al-Islami, Cet. 3, (Mesir: Dar al-Yasar, 2006), hal. 23.

[32]Muhammad at-Tahir Ibn Asyir, Maqasid al-Syariah al-Islamiyah, Cet.2, (Jordan: Dar an-Nafais, 2001), hal. 278.

[33]M. Thaher Azhary, "Wakaf dan Sumber Daya Ekonomi, Suatu Pendekatan Teoritis",Mimbar Hukum No. 7 Tahun ke-3, 1992, Al-Hikmah dan Direktorat Pembinaan Badan Peradilan Agama Islam,Jakarta, hal. 13. 